tonic pupil is described for the first time in English medical literature. In one of the cases shown to the Society I found the tonic pupil associated with absence of the knee jerks. This was the first observation of its kind.

Yours faithfully,

Charles Markus.

27, Wimpole Street, W.1

February 11th, 1942.

\title{
OBITUARY
}

\section{JOHN GRAY CLEGG}

BRITISH Ophthalmology has lost one of her outstanding personalities in the death of John Gray Clegg, which occurred in December last at Epsom, where he had been living in retirement for some time. There are few of us to whom he was not known and though lately his appearances had been less frequent, his passing leaves a gap in our ranks which it will be difficult to fill.

Clegg was from the North and of the North and he was always proud of his association with this part of the country. There was much of northern ruggedness in his characteristics and outlook on life. Of Manchester parents, he was educated at a famous Manchester school and later at its University where he had a brilliant career as a student.

From his early medical days his interest was centred on ophthalmology and after a short period as resident in a general hospital he became attached to the Manchester Royal Eye Hospital and soon became a member of its honorary staff. For forty years he gave it his devoted service, and it was always his first love-his work and his hobby combined. He held one other major appointment, that of honorary ophthalmic surgeon to the Manchester Royal Infirmary; here he followed in the footsteps of David Little and Hill Griffiths and enhanced the great traditions which they had built up. He resigned this post in 1924 and ceased his active association with the Royal Eye Hospital seven years later. At the British Medical Association meeting in Manchester in 1928, he was elected President of the Ophthalmological section.

Scientific meetings claimed a great deal of his time; he was one of a small group who were instrumental in founding the North of England Ophthalmologieal Society and rarely missed a meeting. In his own hospital, he would usually show an abundance of cases 
and could always be found the centre of a group discussing the problems he had brought forward. In the subsequent discussion, his knowledge and experience were freely shared with other members. The United Kingdom meetings and Oxford found him a regular attendant and he never ceased to encourage younger men to take an active part in scientific gatherings. He published a large number of papers and travelled both on the continent and in America, where he was particularly well known as a leading British Ophthalmologist.

In medicine, as in other walks of life, a leader possesses certain characteristics that place him above his fellows-a keen intellect, a massive knowledge of his subject, experience and memory. Clegg enjoyed all these, but in addition there was added that rarer gift, perhaps best described as "flair." In his prime, no case and no ophthalmic problem seemed beyond him. He was particularly at his best in expressing an opinion on what we term a "difficult case" - a diagnosis of early intra-ocular tumour or the decision to remove a potentially dangerous eye. His examination of patients was meticulous; only once over many years do I remember his missing an obvious clinical point. So was his note-taking, both in hospital and private practice. He used to teach that the value of note-taking was twofold. First, it provided a permanent irrefutable record, and secondly, it demanded a constant accurate examination by the observer. Younger men would do well to ponder this latter point and learn by it. As an operator, he was sound rather than brilliant, thoughtful rather than spectacular, but for concentration in attention to detail he was probably never surpassed-one thinks of his consistency of perfection in cataract sections as but one example.

Successful ophthalmologists lead a busy life and Clegg was no exception. He had an enormous private practice, but gave much of his time to his hospital patients. He was always striving for something better and his knowledge and experience enabled him quickly to form a judgment as to the value of a suggested new line of treatment-though there was nothing but contempt for the "flashy" and unscientific cure.

He was something of a character, jovial and hearty and always ready to share a joke, for him or against him. A generation of residents will remember his dashes from the hospital-late for his appointments - and the sleeves of his macintosh trailing behind him as he rushed for tram or taxi.

Perhaps two incidents of personal knowledge give a key to his greatness. As is the custom, his application for an important hospital appointment contained numerous testimonials. One was from a famous surgeon, and was quite brief. It read thus: "I have known Mr. J. Gray Clegg for many years. I consider that 
any hospital that obtains his services must be considered very fortunate." The second incident was more recent : in conversation with a famous London ophthalmic surgeon the latter remarked: "I never met Clegg without learning something from him."

Spiritually, mentally and physically, Clegg was a large scale man. He devoted much of his time to the Mlethodist Church of which he was a great supporter. He was a life-long abstainer and nonsmoker. In his younger days, Clegg lived a lonely life, dividing his time between his Church, his hospital and his private practice. Later he found great happiness and to his widow we extend our deepest sympathy.

\section{NOTES}

William Mackenzie

THE William Mackenzie Memorial Medal has Memorial Medal been awarded to Dr. A. J. Ballantyne, formerly Professor of Ophthalmology at Glasgow University. Dr. Ballantyne hopes to give the customary address at the Glasgow Eye Infirmary in May at the meeting of the Section of Ophthalmology of the Royal Society of Medicine.

Oxford Ophthalmological Congress

THE Oxford Ophthalmological Congress will be held on July 2 and 3, 1942. As accommodation is very linited early application is advised. Further information from Dr. F. A. Anderson, 12, St. John's Hill, Shrewsbury.

Special Notice

WE are asked by the Ministry of Information to state that the fact that goods made of raw materials in short supply owing to war conditions are advertised in this journal should not be taken as an indication that they are necessarily available for export.

\section{FUTURE ARRANGEMENTS}

\section{2}

July 2, 3, 1942.-Oxford Ophthalmological Congress, at Oxford. 